\title{
Can strategic corporate social responsibility drive corporate innovation?
}

\begin{tabular}{|c|c|}
\hline $\begin{array}{l}\text { Authors: } \\
\text { Zhenzhen Yan } \\
\text { Hanning Su² } \\
\text { Wenzhang Su }\end{array}$ & \\
\hline $\begin{array}{l}\text { Affiliations: } \\
{ }^{1} \text { Department } \\
\text { Faculty of Sch } \\
\text { Accounting, D } \\
\text { University of } \\
\text { Economics, D }\end{array}$ & $\begin{array}{l}\text { of Auditing, } \\
\text { ool of } \\
\text { ongbei } \\
\text {-inance and } \\
\text { alian, China }\end{array}$ \\
\hline $\begin{array}{l}{ }^{2} \text { Department } \\
\text { Faculty of Bus } \\
\text { Economics, Tr } \\
\text { Melbourne, N } \\
\text { Australia }\end{array}$ & $\begin{array}{l}\text { of Economics, } \\
\text { iness and } \\
\text { ee University of } \\
\text { lelbourne, }\end{array}$ \\
\hline $\begin{array}{l}\text { Correspondin } \\
\text { Hanning Su, } \\
\text { suhanning199 }\end{array}$ & $\begin{array}{l}\text { g author: } \\
\text { 7@gmail.com }\end{array}$ \\
\hline $\begin{array}{l}\text { Dates: } \\
\text { Received: } 10 \\
\text { Accepted: } 16 \\
\text { Published: } 30\end{array}$ & $\begin{array}{l}\text { Eeb. } 2021 \\
\text { Sept. } 2021 \\
\text { Nov. } 2021\end{array}$ \\
\hline $\begin{array}{l}\text { How to cite th } \\
\text { Yang, Z., Su, H } \\
\text { (2021). Can st } \\
\text { corporate soc } \\
\text { responsibility } \\
\text { innovation? S } \\
\text { Journal of Bus } \\
\text { Management, } \\
\text { https://doi.or } \\
\text { sajbm.v52i1.2 }\end{array}$ & $\begin{array}{l}\text { is article: } \\
\text {., \& Sun, W. } \\
\text { rategic } \\
\text { ial } \\
\text { drive corporate } \\
\text { outh African } \\
\text { iness } \\
52(1), \text { a2577. } \\
\text { g/10.4102/ } \\
577\end{array}$ \\
\hline $\begin{array}{l}\text { Copyright: } \\
\text { (c) 2021. The } \\
\text { Licensee: AOS } \\
\text { is licensed un } \\
\text { Creative Com } \\
\text { Attribution Lic }\end{array}$ & $\begin{array}{l}\text { uthors. } \\
\text { IS. This work } \\
\text { der the } \\
\text { nons } \\
\text { ense. }\end{array}$ \\
\hline Read online: & \\
\hline 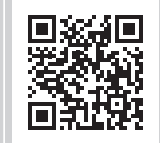 & $\begin{array}{l}\text { Scan this QR } \\
\text { code with your } \\
\text { smart phone or } \\
\text { mobile device } \\
\text { to read online. }\end{array}$ \\
\hline
\end{tabular}

Purpose: In practice, an increasing number of economic entities have begun to consider strategic corporate social responsibility (CSR) as an opportunity to create a win-win situation for the organisation and the society. The existing literature has yet to soundly corroborate the role of strategic CSR in corporate innovation. This study examines the relationship between strategic CSR and innovation.

Design/methodology/approach: The empirical regression models are estimated to analyse the data collected from 2817 firms yielding 18845 firm-year observations from 2001 to 2014 in the United States.

Findings/results: The findings indicate that firms with strategic CSR generate more and better innovation outputs. The positive effect is more pronounced when institutional ownership is lower, when firm size is larger, and when product market competition is more intense. In terms of economic consequences, firms with strategic CSR actually have higher commercial value and are less likely to suffer loss from failed innovation.

Practical implications: To establish a sustainable relationship with stakeholders and realise the long-term development of business and society, enterprises should engage in strategic CSR in a planned manner based on their own resources and professional expertise.

Originality/value: The study sheds light on a growing body of literature that investigates the real consequences of firms' strategic CSR, and explains the growing recognition of the importance of strategic CSR.

Keywords: strategic corporate social responsibility; responsive corporate social responsibility; long-term development; corporate innovation; radical patents.

\section{Introduction}

Corporate social responsibility (CSR) has received great attention in most countries over the past two decades as an action plan for companies to implement sustainable development. Evidence shows that institutional and individual investors now consider environmental or social effects in making investment decisions (Chen, Dong, \& Lin, 2020; Heinkel, Kraus, \& Zechner, 2001; Riedl \& Smeets, 2017). Generally, CSR is an attempt to respond to stakeholders' demand and indicates a shift from a shareholder view to a stakeholder view of the firm (Dal Maso, Lobo, Mazzi, \& Paugam, 2020; Magill, Quinzii, \& Rochet, 2015). However, investing in positive CSR policies is costly and the expected benefits may fall short of the costs (Chen, Hung, \& Wang, 2017). Thus, it is important to improve our understanding of CSR sustainability. Determining how CSR affects the long-term development capability of companies from the perspective of innovation is necessary.

Traditional CSR is disconnected from business and strategy (Carroll, 1991; Porter \& Kramer, 2006), which indicates that this type of investment may be unsustainable. In response to the concerns about traditional CSR, the concept of CSR has gradually evolved into strategic CSR (SCSR) with the development of economy. Strategic Corporate social responsibility is a sustainable strategic action that adds social good whilst benefitting firms financially. That is, when CSR is integrated with firms' business strategies and helps organisations achieve strategic objectives, it is regarded as SCSR (McWilliams \& Siegel, 2011; Porter \& Kramer, 2006). In practice, some economic entities have considered SCSR as an opportunity to create a win-win situation for the organisation and the society, rather than a cost, a charitable deed, a damage-control mission, or a public relations (PR) campaign. Thus, an interesting question is how firms do well by doing good. It is important to focus not only on the immediate financial impact of SCSR, but also on the long-term benefits, especially corporate innovation that is critical to the long-term development of the company. However, existing literature 
has yet to soundly corroborate the role of SCSR in the corporate innovation development. The answer to this question may shed light on the strategic intent behind engaging in SCSR. It not only gains the attention of companies and shareholders, but also the interest of other stakeholders, such as the government, customers, suppliers, community groups, and underrepresented groups.

Although the relationship between SCSR and corporate innovation has not been empirically captured by prior research, some studies have shown the relationship between traditional CSR and corporate innovation, and the results are generally mixed. Specifically, some studies have argued that traditional CSR has a positive influence on corporate innovation (Bocquet \& Mothe, 2011; Luo \& Du, 2015; Martinez-Conesa, Soto-Acosta, \& Palacios-Manzano, 2017; Mishra, 2017; Wu, Liu, Chin, \& Zhu, 2018), whereas others provide evidence in the opposite direction (Gallego-Álvarez, Prado- Lorenzo, \& García- Sánchez, 2011; Mithani, 2017). One important reason for this ambiguity may be that CSR has been transforming from being perceived as a cost into becoming a strategic investment (Cochran, 2007). On the basis of resource-based view and optimal distinctiveness framework, traditional CSR, such as charity, has no significant heterogeneity between firms, whereas SCSR is a unique positioning strategy that can help firms obtain abundant opportunities and resources for innovation.

To fill this gap, this study initially considers the effects of distinct CSR behaviours (strategic vs. responsive) on the quantity of innovation. To identify the heterogeneity in the innovative strategies of firms, we then illustrate how SCSR affects the quality of innovation measured by patent citations. Moreover, SCSR may relate to different aspects, such as environment and employee relations. Some of these aspects can be combined with corporate specialty, whereas others cannot. Enterprises can freely decide whether to allocate resources in aspects that fully utilise the core professional advantages gained from the main business. We classify the former as focused SCSR (FSCSR) and the latter as diffused SCSR to examine the effects of different practices of SCSR on corporate innovation. Finally, the possible channels through which SCSR affects corporate innovation and the crosssectional heterogeneity in the results are examined.

Using a sample of US public firms from 2000 to 2014, we find that firms with SCSR generate more and higher-quality innovation outputs than those with responsive CSR. In comparison with diffused SCSR, FSCSR contributes more to innovation. These results are robust to a series of robustness checks, including alternative model, alternative measures of variables, alternative sample, potentially omitted variable tests, propensity score matching (PSM) approach, and instrumental variable approach. Further analyses indicate that SCSR improves tolerance for failure and reduces shortterm performance pressure, which is critical to the success of innovation. Moreover, consistent engagement of SCSR matters to innovation. In terms of economic consequences, firms with SCSR have higher commercial value and suffer fewer loss from failed innovation. In terms of cross-sectional heterogeneities, the positive effect of SCSR on innovation is more pronounced when institutional ownership is lower, when firm size is larger, and when product market competition is more intense. In summary, our evidence suggests that SCSR has an inspiring bright side, that is, it matters to innovation.

Our study provides at least two contributions to the existing literature. Firstly, our study sheds light on a small but growing body of literature that investigates the real consequences of firms' SCSR practice. Different types of CSR require vastly different skills and resources to operate. Some literature in economics and management attempts to distinguish different types of CSR activity to evaluate their contributions to firms' future development (Khan, Serafeim, \& Yoon, 2016; Planer-Friedrich \& Sahm, 2020). However, most of them are conceptual and qualitative (Bagnoli \& Watts, 2003; Baron, 2009). A systematic overview and empirical evidence of the relationship between different types of CSR and innovation are still lacking. We examine how firms' CSR engagement strategy (strategic vs. responsive) affects innovation and find that SCSR, especially FSCSR, is associated with more and higher-quality patents. The results explain the growing recognition of the importance of SCSR. Our evidence suggests that firms can utilise CSR to enhance firm value.

Secondly, this study adds to the research on the driving forces of high-quality corporate innovation. High-quality innovation is the core of promoting high-quality development (Moshirian, Tian, Zhang, \& Zhang, 2020). Generally, current research explores various factors that affect innovation, such as institutional ownership (Aghion, Van Reenen, \& Zingales, 2013), antitakeover provisions (Atanassov, 2012; Chemmanur \& Tian, 2018), stock options (Chang, Fu, Low, \& Zhang, 2015), and employee treatment (Chen, Chen, Hsu, Podolski, 2016). Our study adds to this strand of literature by recognising SCSR engagement as an important driver of high-quality innovation.

\section{Literature review}

A large literature argues that innovation is essential for firms to achieve sustainable development and is affected by various factors, including economic factors (Aghion, Bloom, Blundell, Griffith, \& Howitt, 2005), government and law, regulations and policy factors (Moser, 2005), cultural and ethical factors (Abdullah, Shamsuddin, Wahab, \& Hamidet, 2014), environmental ethics (Chang, 2011), and other factors (Manso, 2011; Sunder, Sunders, \& Zhang, 2017; Tsai \& Liao, 2017). These factors involve various corporate stakeholders, and these stakeholders are also the main considerations of CSR.

On the basis of resource dependence theory, organisations are constrained and affected by their environment. Thus, firms should interact with the environment they rely on, which has given rise to CSR activities. According to Zhang, Wang and Zhou (2020), the effects of conforming and 
distinctive CSR practices on the organisation development are different. Following the resource-based view, business resources will contribute to organisations' competitive advantage the most if they are valuable, rare, inimitable, and non-substitutable (Choi \& Wang, 2009; Hillman \& Keim, 2001; Melo \& Garrido-Morgado, 2012). The notion of optimal distinctiveness provides similar perspective by addressing that firms will benefit most by differentiating themselves from their peers through the differentiation of their social activities and the demands of their stakeholders (Zhang et al., 2020).

Traditional CSR has no significant heterogeneity amongst firms. Conversely, SCSR is a unique positioning strategy and acts as a way to differentiate a firm from its competitors to achieve a competitive advantage and a win-win situation to both the organisation and society (Bénabou \& Tirole, 2010; McWilliams, Siegel, \& Wright, 2006). The concept of SCSR was coined by Baron (2001) to refer to a strategic approach that can integrate corporate strategy with CSR efforts. According to Porter and Kramer (2006), companies should embrace SCSR and select the social issues that intersect with their particular strategy. Some studies show a positive relationship between SCSR and value creation (Husted \& Allen, 2007) or financial performance (Michelon, Boesso, \& Kumar, 2013), a negative relationship between SCSR and information asymmetry between consumers and producers (Belu \& Manescu, 2013). However, other studies have found that SCSR has a neutral impact on corporate performance (Belu \& Manescu, 2013) and that SCSR is undertaken only to the extent that marginal cost equals marginal benefit.

In general, although there has been a growing awareness regarding SCSR, the evidence on the effect of SCSR activities on corporate performance is mixed. Moreover, there is no empirical study on the effect of SCSR on corporate innovation. This study, therefore, contributes to the literature by providing insight into the effect of SCSR on the quantity and quality of corporate innovation. It further provides valuable evidence that SCSR helps both the organisation and the society to have a win-win situation.

\section{Research methodology}

Based on the above-mentioned literature, this study puts forward research hypotheses and further tests hypotheses using empirical research method. The main steps are as follows:

Step 1: Hypothesis development. Based on the research objectives and the literature review, set up research hypotheses to make the testable predictions.

Step 2: Sample selection. Select a good sample and appropriate sample size to test research hypotheses.

Step 3: Empirical specification. Select regression model, define and measure dependent variables, independent variables and control variables in order to analyse the data in the research.

\section{Hypothesis development}

Holmström (1989) argues that innovation requires risktaking. A 'failure-tolerant' environment that does not punish early failures is critical to the success of innovation (Manso, 2011). Most firms increasingly perceive SCSR as a strategic investment in intangible assets rather than a cost (Isaksson, Kiessling, \& Harvey, 2014). They can directly or implicitly convey some critical information about corporate innovation strategy or risks of failure in its SCSR communication. The SCSR communication helps to reduce information asymmetry (Foreh \& Grier, 2003), helps stakeholder understand innovation process, and tolerate early failures. Visible SCSR activities also help companies build improved image and reputation that can be used as an insurance-like protection in the event of negative actions (McWilliams \& Siegel, 2011), such as failure in the process of corporate innovation, and can be conducive to establish beliefs that corporate innovation will eventually succeed after trying. As a result, greater trust creates a failure-tolerant environment in which companies are willing to invest in innovation and increase the quantity of innovation.

Mitigating short-termism of managers is crucial to foster innovation (Holmström, 1989). Managers may view CSR as a liability that dampens performance or a smokescreen that covers up their poor performance. This short-termism is one reason why a long-standing criticism of responsive CSR exists and why SCSR, which considers long-term benefits without neglecting short-term requirements, has become a widely recognised concept and practice. In comparison with CSR projects in areas little understood by firms, SCSR leads to cost reductions by making firms focus their CSR projects on activities within the expertise (Husted \& Allen, 2009). Previous studies have illustrated that the strategic use of CSR fosters market concentration and contributes to a high level of corporate financial performance (Boesso, Favotto, \& Michelon, 2015; Michelon et al., 2013), thereby mitigating management's focus on short-term performance pressure, which is conducive to stimulating innovation and promoting the quantity of corporate innovation. On the basis of the arguments stated above, we hypothesise the following:

H1: Strategic CSR is positively associated with the quantity of corporate innovation.

Firms with SCSR are inclined to invest more in innovation, which will increase the quantity of corporate innovation. However, one may wonder whether SCSR, whilst promoting the quantity of innovation, will help improve the quality of innovation. After all, high-quality innovation is more likely to bring the fundamental changes in a technological trajectory and provide a potential opportunity to enter emerging markets.

Building upon the knowledge-based view and the organisational learning perspective, some studies have recognised that knowledge is a direct driver of high-quality innovation (Flor, Cooper, \& Oltra, 2017; Forés \& Camisón, 2016; Zhou \& Li, 2012). In comparison with responsive CSR, 
SCSR enables firms to establish broader and deeper relationship networks with their stakeholders. A strong stakeholder-firm relationship facilitates stakeholders to voluntarily share and exchange ideas, resources, and information with companies (Luo \& Du, 2015; Tsai \& Ghoshal, 1998). The external knowledge possessed by stakeholders, that includes market preferences, latent needs, expertise, or experience, is often fresh and can thus complement the firms' internal knowledge and broaden their knowledge base. The interaction of internal knowledge and heterogeneous external knowledge further stimulates organisational learning and increases the possibility of origination and implementation of good innovative ideas. From an absorptive capacity perspective, different CSR engagement strategies can affect how much a firm ultimately benefits from CSR. Sydow, Schreyögg and Koch (2009) believe that the similarities or differences of involved events determine the complexity of coordination work between these events. Strategic CSR engagement is closely related to enterprises, and the new knowledge, competencies, and resources acquired from these activities are related or compatible. Companies can recognise, understand, and exploit this knowledge to transform innovative ideas into high-quality innovation when they already have knowledge that is moderately related to the new information.

Employees are the most valuable asset and the most important innovator of firms (Mao \& Weathers, 2019). Many corporations use CSR as an employee governance tool (Flammer \& Luo, 2017). In comparison with responsive CSR, firms engaged in SCSR make the right employees feel more secure in their job roles, because SCSR activities can clearly convey the developing direction, developing strategy, and development prospect of companies. Job security promotes a tolerance for early failure and motivates employees to participate in high-quality innovation and take more risks when innovating (Manso, 2011). Willard (2012) argues that recruitment, retention, and productivity are the three human resource advantages of CSR. Good SCSR practices help attract and retain highly talented employees and improve their efficiency and productivity, which can enhance highquality innovation. Turban and Cable (2003) and Stuebs and Sun (2010) explain this notion as employees considering such firms as more reputable, fairer, more sharing, more responsible, and more sustainable employers. The open environment brought about by SCSR practices allows employees to communicate and collaborate freely with other teams, thereby generating good innovative ideas.

As such, SCSR improves the quality of innovation through the accumulation and absorption of external knowledge and excellent human capital. For all these reasons, we hypothesise the following:

H2: Strategic CSR is positively associated with the quality of corporate innovation.

Strategic corporate social responsibilitymay relate to different aspects, such as environment, community, diversity, employee relations, and human rights. Enterprises can freely choose any of these aspects. The theory of planned behaviour argues that human behaviour is the result of a well-thoughtout plan (Ajzen, 1991). As rational actors, firms are inclined to seriously consider and weigh the resource allocation of SCSR. They may allocate resources in areas that fully utilise the specialty gained from the main business or in areas that do not need to be integrated with their core specialty. We classify the former as FSCSR and the latter as diffused SCSR. For example, Patagonia, the California-based outdoor and sportswear manufacturer, combines environmental protection with its products. Patagonia uses both synthetic and natural fibres made from pre-consumer and postconsumer waste to make clothes, and is trying to use $100 \%$ renewable and recycled raw materials to reducing carbon emissions. This example is the typical FSCSR we are referring in this study. Managers may wonder how to choose between FSCSR that makes the firm unique or diffused SCSR that makes the firm less unique. Next, we attempt to compare the efficacies of the two choices in terms of corporate innovation.

A firm using diffused SCSR may find it difficult for their CSR practices to be impressive. If firms focus on aspects such as employee relations, diversity, or human rights, then they have few opportunities to take advantage of their unique specialty. The CSR practices of such firms nearly have no essential difference. One of the results is difficulty in accelerating the flow, sharing, and transformation of innovation elements, making the promotion of innovation also difficult. By contrast, a firm adopting FSCSR actively identifies and prioritises the aspects of CSR that are most relevant to its unique specialty. More concentrated efforts enable firms to have a close contact with potential customers to obtain the latest and most useful knowledge that is easy to digest and absorb. Such efforts also allow firms to find out new opportunities that are difficult to discover in an ordinary approach, such as proprietary data on new trends that enable companies to innovate to meet new market expectations. Highly focused CSR projects within the expertise of firms are more likely to reduce cost and create value (Husted \& Allen, 2009). Focused SCSR also contributes to promoting and popularising new products and conveying innovative ideas, thereby contributing to realising commercial value of innovation and stimulating innovation. Summarising the above arguments, we hypothesise:

H3: In comparison with diffused SCSR, FSCSR contributes more to high-quality innovation.

\section{Sample selection}

The patent and citation data are collected from three sources. We begin with the National Bureau of Economic Research Patent Citation database, which covers all granted patents in the United States from 1976 to 2006. We then extend this database through 2017 with the patent data created by Kogan, Papanikolaou, Seru and Stoffman (2017) and Stoffman, Woeppel and Yavuz (2019). There may be two types of truncation problems related to patent and citation data. The first type of truncation bias mainly affects the metric of patent count. Given the considerable lag between patent application and the grant (an average of 2 years), 
patents that are applied for but are still under review by 2017, the last year in the database, are unavailable for observation. To reduce this concern, observations after 2014 are excluded. Another truncation problem mainly affects the metric of patent citations. Following fixed effects approach (Hall, Jaffe, \& Trajtenberg, 2001), we scale the citation counts by the average citation counts of all patents applied for in the same technology class and the same year. Therefore, the second type of truncation deviation has been mitigated.

The CSR data are collected from Morgan Stanley Capital International Environmental, Social and Governance, and Kinder, Lydenberg, Domini (MSCI ESG KLD) database. MSCI ESG KLD database is an annual data set applied to numerous publicly traded companies and has been widely used in numerous studies (Deng, Kang, \& Low, 2013; Hong \& Kostovetsky, 2012; Krüger, 2015; Servaes \& Tamayo, 2013). We obtain firm financial data from the CRSP/ Compustat Merged annual file to construct control variables. Financial firms and utilities (Standard Industrial Classification [SIC] codes 4900-4999 and 6000-6999) are excluded. Firm-year observations with missing values are also eliminated. All continuous variables are winsorized at $1 \%$ level breakpoints to avoid problems with outliers. The final main sample comprises 2817 firms, yielding 18845 firm-year observations from 2001 to 2014.

\section{Empirical specification}

To examine the relationship between SCSR and corporate innovation, we estimate the following regression:

Innovation $_{i, t}=\alpha_{0}+\alpha_{1}$

$\operatorname{SCSR}_{i, t-1}\left(\operatorname{FSCSR}_{i, t-1}\right)+\alpha_{2}$

Controls $_{i, t-1}+\alpha_{3}$

Industry $y_{i, t}+\alpha_{4}$

Year $_{t}+\varepsilon_{i, t}$

where $i$ denotes firms, and $t$ denotes years; Industry is the two-digit SIC industry fixed effects, and Year represents the year fixed effects; Innovation captures different measures of innovation, including patent and citation, referring to the total number of patents and citations, respectively; and Controls is a vector of control variables that affect a firms' innovation performance based on the extant literature.

\section{Measuring the quantity and quality of innovation}

In comparison with input-oriented measures of innovation, output-oriented measures are less noisy and closer to the actual value of innovation (Atanassov, 2012). Our first output-oriented metric is the number of patents (Patent) that the firm applies for each firm-year observation (and eventually granted) to be a proxy for the quantity of innovation. However, this measure imperfectly captures the variation in technological and economical importance of patents (Aghion et al., 2013; Hall, Jaffe, \& Trajtenberg, 2005). We therefore construct the second output-oriented metrics to be proxies for innovation quality based on the number of forward citations, which refer to the citations that a patent receives from subsequent patents. The more subsequent citations a patent applies for in a given year, the higher the quality of innovation will be.

\section{Strategic corporate social responsibility measurement}

The concept of SCSR was coined by Baron (2001) and subsequently developed by Waldman, Siegel and Javidan (2006) and McWilliams and Siegel (2011). In the latest research, SCSR is defined as activities that further social good whilst benefitting firms financially (Vishwanathan, Van Oosterhout, Heugens, Duran, \& Van Essen, 2020). Thus, so far, direct measurement of SCSR remains lacking (Vishwanathan et al., 2020), including the degree of integration of CSR practices with firms' business strategies. Nevertheless, SCSR has obvious advantages over responsive charitable donations, because it is essentially an investment and well supported by shareholders and other stakeholders. Mcwilliams et al. (2006) argue that SCSR can be a differentiation strategy at the company level and should be regarded as a form of strategic investment. Accordingly, firms will invest more in SCSR than in responsive CSR. In accordance with this idea, we construct SCSR as follows.

MSCI ESG KLD STATS database contains 13 dimensions of CSR. As in prior studies (Lins, Servaes, \& Tamayo, 2016; Servaes \& Tamayo, 2013), we mainly focus on five dimensions: community, diversity, employee relations, environment, and human rights. We exclude the product and corporate governance in our analyses because they are generally indispensable parts in the management and production of enterprises and not parts of firms' CSR remit. Moreover, we do not consider six controversial industries and the corresponding dimensions (namely, alcohol, gambling, firearms, military, nuclear, and tobacco), because companies operating in these industries have little to do to change their scores except to exit these industries. Specifically, we initially divide the number of strengths (concerns) for each of the five categories by the maximum number of strengths (concerns) possible for the same category and the same year to obtain the strengths (concerns) index, which ranges from 0 to 1 for each categoryyear. Then, we subtract the concerns index from the strengths index to obtain the net CSR index in each category-year, which ranges from -1 to +1 . A firm's total CSR score is computed as the sum of the net CSR indices for the five categories. Finally, following Michelon et al. (2013) and Boesso et al. (2015), our explanatory variable, SCSR, is equal to 1 if a firm's total CSR score is higher than the overall mean for a given year, and 0 otherwise. We classify the firm as addressing CSR in a strategic way if a firm's SCSR is equal to 1.

\section{Focused strategic corporate social responsibility measurement}

To measure FSCSR, we initially divide SCSR into two groups according to whether it can be combined with corporate unique expertise, and we then construct a dummy variable, FSCSR, to measure it. The first group includes environment and community, and the second group includes employee relations, diversity, and human rights. Focused SCSR equals to 1 if the strengths index of environment or community aspects of SCSR is greater than zero, and 0 otherwise. The 
strengths index indicates the extent to which the company actively participates in the environment or the community and also indicates the extent to which the company uses its expertise when participating in SCSR.

\section{Control variables}

Following the innovation literature, we include a rich set of firm characteristics. Innovation input (RD/Sales) is measured by the ratio of Research \& Development (R\&D) expenditures to sales; firm size (Ln[Sales]) is measured by the natural logarithm of sales; capital structure (LEV) is the ratio of total debt to total assets; operating profitability (ROA) is the ratio of earnings before interest, taxes, depreciation, and amortisation to book value of total assets; cash holding (Cash/Assets) is the ratio of cash to total assets; sales growth (SalesGrowth) is the growth in sales; market-to-book ratio (M/B) is the ratio of the market value of equity to the book value of equity; capital expenditures (CapEx/Assets) is the ratio of capital expenditures to total assets; capital intensity (Ln[PPE/EMP]) is the natural logarithm of the ratio of net property, plant, and equipment to the number of employees; and labour productivity and quality ( $\mathrm{Ln}[$ Sales/EMP]) is the natural logarithm of the ratio of sales to the number of employees. All control variables are lagged by 1 year. As mentioned earlier, year fixed effects and two-digit SIC industry fixed effects are included in our regression to account for the systematic variation in dependent variables across year and industry.

\section{Ethical considerations}

This article followed all ethical standards for research without direct contact with human or animal subjects.

\section{Results \\ Descriptive statistics}

Panels A-C of Table 1 report the summary statistics. Panel A shows that the distribution of Patent (Citation) is skewed, with a mean value of 24.296 (39.743) and a median value of $0(0)$. Firms in our sample generate approximately 24 patents and receive approximately 40 total citations per year. With respect to our variable of interest, SCSR, the mean value is 0.439 , which indicates that on average, $43.9 \%$ of firm-year observations engage in CSR strategically. The mean value of FSCSR is 0.196 , indicating that on average, only $19.6 \%$ of firm-year observations engage in FSCSR.

Panels B and C report the summary statistics for subsamples of firms with SCSR and FSCSR, respectively. Comparing the results of three panels, we can find that the average value of Patent presents an increasing trend. The average value of Citation is also increasing. Consistent with our conjectures, these results demonstrate that firms with SCSR generates more and better innovation outputs, and compared with diffused SCSR, firms with FSCSR tend to have more and better innovation outputs on average.

\section{Univariate analyses}

In Panel A of Table 2, we compare the means across subsamples of firms with and without SCSR and calculate the differences in the mean values of Patent and Citation, respectively. The univariate tests show that innovation outputs in SCSR subsets are considerably more than those in non-SCSR subsets. Column (5) shows that the differences are all statistically

TABLE 1: Summary statistics.

\begin{tabular}{|c|c|c|c|c|c|c|c|c|}
\hline Variables & $N$ & Mean & SD & P10 & P25 & Median & P75 & P90 \\
\hline \multicolumn{9}{|c|}{ Panel A: Summary statistics for full sample } \\
\hline Patent & 18845 & 24.296 & 91.127 & 0 & 0 & 0 & 6 & 41 \\
\hline Citation & 18845 & 39.743 & 150.294 & 0 & 0 & 0 & 6.408 & 65.878 \\
\hline SCSR & 18845 & 0.439 & 0.496 & 0 & 0 & 0 & 1 & 1 \\
\hline FSCSR & 18845 & 0.196 & 0.397 & 0 & 0 & 0 & 0 & 1 \\
\hline RD/Sales & 18845 & 0.162 & 0.675 & 0 & 0 & 0.006 & 0.079 & 0.210 \\
\hline Ln(Sales) & 18845 & 6.870 & 1.828 & 4.664 & 5.706 & 6.823 & 8.060 & 9.214 \\
\hline LEV & 18845 & 0.491 & 0.241 & 0.183 & 0.310 & 0.484 & 0.635 & 0.790 \\
\hline ROA & 18845 & 0.113 & 0.143 & -0.003 & 0.077 & 0.127 & 0.180 & 0.243 \\
\hline Cash/Assets & 18845 & 0.137 & 0.139 & 0.013 & 0.036 & 0.094 & 0.191 & 0.319 \\
\hline SalesGrowth & 18845 & 0.130 & 0.304 & -0.126 & -0.002 & 0.084 & 0.201 & 0.395 \\
\hline $\mathrm{M} / \mathrm{B}$ & 18845 & 3.139 & 4.161 & 0.970 & 1.479 & 2.337 & 3.803 & 6.550 \\
\hline CapEx/Assets & 18845 & 0.051 & 0.054 & 0.009 & 0.018 & 0.033 & 0.062 & 0.111 \\
\hline Ln(PPE/EMP) & 18845 & 3.964 & 1.404 & 2.482 & 3.089 & 3.766 & 4.601 & 5.713 \\
\hline Ln(Sales/EMP) & 18845 & 5.607 & 0.866 & 4.645 & 5.130 & 5.575 & 6.059 & 6.654 \\
\hline \multicolumn{9}{|c|}{ Panel B: Summary statistics for subsample of firms with SCSR } \\
\hline Patent & 8264 & 38.516 & 117.862 & 0 & 0 & 0 & 13 & 86 \\
\hline Citation & 8264 & 61.864 & 191.902 & 0 & 0 & 0 & 16.229 & 144.109 \\
\hline SCSR & 8264 & 1 & 0 & 1 & 1 & 1 & 1 & 1 \\
\hline FSCSR & 8264 & 0.338 & 0.473 & 0 & 0 & 0 & 1 & 1 \\
\hline \multicolumn{9}{|c|}{ Panel C: Summary statistics for subsample of firms with FSCSR } \\
\hline Patent & 2797 & 91.523 & 180.151 & 0 & 0 & 9 & 78 & 341 \\
\hline Citation & 2797 & 140.277 & 286.921 & 0 & 0 & 7.817 & 112.068 & 519.127 \\
\hline SCSR & 2797 & 1 & 0 & 1 & 1 & 1 & 1 & 1 \\
\hline FSCSR & 2797 & 1 & 0 & 1 & 1 & 1 & 1 & 1 \\
\hline
\end{tabular}

SCSR, strategic corporate social responsibility; FSCSR, focused strategic corporate social responsibility; RD, research and development expenditures; Ln, natural logarithm; LEV, capital structure; $\mathrm{ROA}$, operating profitability; M/B, market-to-book ratio; CapEx, capital expenditures; PPE, net property, plant, and equipment; EMP, employees; SD, standard deviation. 
TABLE 2A: Univariate analyses.

\begin{tabular}{|c|c|c|c|c|c|}
\hline \multirow[t]{2}{*}{ Variable } & \multicolumn{2}{|c|}{$\operatorname{SCSR}(N=8264)$} & \multicolumn{2}{|c|}{ Non-SCSR $(N=10581)$} & \multirow{2}{*}{$\begin{array}{c}\begin{array}{c}\text { Test of } \\
\text { difference }\end{array} \\
\begin{array}{c}(1)-(3) \\
(5)\end{array}\end{array}$} \\
\hline & $\begin{array}{c}\text { Mean } \\
\text { (1) }\end{array}$ & $\begin{array}{l}\text { SD } \\
\text { (2) }\end{array}$ & $\begin{array}{l}\text { Mean } \\
\text { (3) }\end{array}$ & $\begin{array}{l}\text { SD } \\
\text { (4) }\end{array}$ & \\
\hline \multicolumn{6}{|c|}{ Panel A: Innovative outputs partitioned on level of SCSR } \\
\hline Patent & 38.516 & 117.862 & 13.190 & 60.498 & $25.326 * * *$ \\
\hline Citation & 61.864 & 191.902 & 22.466 & 103.873 & $39.398 * * *$ \\
\hline
\end{tabular}

TABLE 2B: Univariate analyses.

\begin{tabular}{|c|c|c|c|c|c|}
\hline \multirow[t]{2}{*}{ Variable } & \multicolumn{2}{|c|}{ FSCSR $(N=2797)$} & \multicolumn{2}{|c|}{ Non-FSCSR $(N=5467)$} & \multirow{2}{*}{$\begin{array}{c}\begin{array}{c}\text { Test of } \\
\text { difference }\end{array} \\
(1)-(3) \\
\text { (5) }\end{array}$} \\
\hline & $\begin{array}{l}\text { Mean } \\
\text { (1) }\end{array}$ & $\begin{array}{l}\text { SD } \\
(2)\end{array}$ & $\begin{array}{l}\text { Mean } \\
\text { (3) }\end{array}$ & $\begin{array}{l}\text { SD } \\
\text { (4) }\end{array}$ & \\
\hline \multicolumn{6}{|c|}{ Panel B: Innovative outputs partitioned on level of FSCSR } \\
\hline Patent & 91.523 & 180.152 & 11.396 & 47.170 & $80.127 * * *$ \\
\hline Citation & 140.277 & 286.921 & 21.748 & 93.830 & $118.529 * * *$ \\
\hline
\end{tabular}

Note: The t-values for mean differences are based on t-tests.

SCSR, strategic corporate social responsibility; FSCSR, focused strategic corporate social responsib.ility; SD, standard deviation.

$* * *, * *$, and $*$, denote significance at the $1 \%, 5 \%$, and $10 \%$ levels, respectively.

TABLE 3: Strategic corporate social responsibility and corporate innovation.

\begin{tabular}{|c|c|c|c|c|}
\hline Variables & $\begin{array}{c}\text { Ln(Patent + 1) } \\
\text { (1) }\end{array}$ & $\begin{array}{c}\operatorname{Ln}(\text { Patent }+1) \\
\text { (2) }\end{array}$ & $\begin{array}{c}\text { Ln(Citation + 1) } \\
\text { (3) }\end{array}$ & $\begin{array}{c}\text { Ln(Citation + 1) } \\
\text { (4) }\end{array}$ \\
\hline \multirow[t]{2}{*}{ SCSR } & $0.549 * * *$ & $0.169 * * *$ & $0.586 * * *$ & $0.186 * * *$ \\
\hline & (10.88) & 4.83 & (10.63) & $(4.72)$ \\
\hline \multirow[t]{2}{*}{ RD/Sales } & - & $0.435 * * *$ & - & $0.485 * * *$ \\
\hline & - & 10.03 & - & (9.54) \\
\hline \multirow[t]{2}{*}{ Ln(Sales) } & - & $0.528 * * *$ & - & $0.560 * * *$ \\
\hline & - & (20.16) & - & (19.65) \\
\hline \multirow[t]{2}{*}{ LEV } & - & $-0.642 * * *$ & - & $-0.725^{* * *}$ \\
\hline & - & $(-5.86)$ & - & $(-5.76)$ \\
\hline \multirow[t]{2}{*}{ ROA } & - & $-0.887 * * *$ & - & $-0.947 * * *$ \\
\hline & - & $(-5.09)$ & - & $(-4.71)$ \\
\hline \multirow[t]{2}{*}{ Cash/Assets } & - & $0.765 * * *$ & - & $0.901 * * *$ \\
\hline & - & $(5.02)$ & - & $(4.88)$ \\
\hline \multirow[t]{2}{*}{ SalesGrowth } & - & $0.060 *$ & - & $0.097^{* *}$ \\
\hline & - & (1.67) & - & (2.18) \\
\hline \multirow[t]{2}{*}{$\mathrm{M} / \mathrm{B}$} & - & $0.025 * * *$ & - & $0.030 * * *$ \\
\hline & - & $(6.72)$ & - & $(6.65)$ \\
\hline \multirow[t]{2}{*}{ CapEx/Assets } & - & -0.590 & - & -0.433 \\
\hline & - & $(-1.36)$ & - & $(-0.91)$ \\
\hline \multirow[t]{2}{*}{ Ln(PPE/EMP) } & - & $0.133^{* * *}$ & - & $0.137 * * *$ \\
\hline & - & $(4.50)$ & - & (4.14) \\
\hline \multirow[t]{2}{*}{ Ln(Sales/EMP) } & - & 0.032 & - & 0.039 \\
\hline & - & $(0.79)$ & - & $(0.87)$ \\
\hline \multirow[t]{2}{*}{ Constant } & $1.500 * * *$ & $-3.060 * * *$ & $1.746 * * *$ & $-3.108 * * *$ \\
\hline & $(3.46)$ & $(-6.74)$ & $(3.47)$ & $(-6.02)$ \\
\hline Industry FE & YES & YES & Yes & Yes \\
\hline Year FE & YES & YES & Yes & Yes \\
\hline$N$ & 18845 & 18845 & 18845 & 18845 \\
\hline Adjusted $R^{2}$ & 0.288 & 0.475 & 0.263 & 0.432 \\
\hline
\end{tabular}

SCSR, strategic corporate social responsibility; RD, research and development expenditures; Ln, natural logarithm; LEV, capital structure; ROA, operating profitability; M/B, market-tobook ratio; CapExu, capital expenditures; PPE, net property, plant, and eqipment; EMP, employees; FE, fixed effects.

$* * *, * *$, and $*$, denote significance at the $1 \%, 5 \%$, and $10 \%$ levels, respectively.

significant at the 1\% level. In Panel B of Table 2, we compare the means across subsamples of firms with and without FSCSR and calculate the differences in the mean values of our measures of innovation outputs. The results show that innovation outputs in FSCSR subsets are considerably more than those in non-FSCSR subsets. Preliminary univariate analyses provide support to our conjectures.

\section{Baseline results}

\section{Strategic corporate social responsibility and corporate innovation}

In Columns (1) and (2) of Table 3, the SCSR coefficients are positive and statistically significant at the $1 \%$ level, indicating that firms with SCSR generate more patents, regardless of excluding or including controls. These results provide strong and consistent evidence to H1. In Columns (3) and (4) of Table 3, the SCSR coefficients are positive and statistically significant, which support H2. In economic terms, the SCSR coefficient in Column (2) implies that SCSR is associated with a patent count that is higher by $17 \%$, and the SCSR coefficient in Column (4) implies that SCSR increases Citation by approximately $19 \%$. The results indicate that firms with SCSR generate more and better innovation outputs than those with responsive CSR.

\section{Focused strategic corporate social responsibility and corporate innovation}

To further investigate the effect of FSCSR on innovation outputs, we run Model (2) using a subsample of firm-year observations with SCSR. In Table 4, the coefficient estimates of FSCSR are positive and significant at the $1 \%$ level. In terms of economic significance, Column (1) of Table 4 shows that FSCSR is associated with a patent count that is higher by $46 \%$. The FSCSR coefficient in Column (2) implies that FSCSR increases Citation by about approximately $47 \%$. These results suggest that compared with diffused SCSR, FSCSR contributes more to the quantity and quality of innovation.

\section{Robustness checks}

In this section, we conduct a series of tests to ensure the robustness of our baseline results, including alternative econometric method, alternative measures of SCSR and FSCSR, reduced sample, tests for potentially omitted variables, PSM approach, instrumental variable approach. The results (untabulated) show that our main findings are unaffected.

\section{Further analyses}

\section{Strategic corporate social responsibility and different categories of innovation}

Although total citations can be a measure of patent quality, it is still noisy and may be caused by multiple incremental patents instead of important or radical patents. Following Azoulay, Graff Zivin and Manso (2011) and Balsmeier, Fleming and Manso (2017), we categorise patents into four non-overlapping categories according to the number of citations that a patent receives from subsequent granted patents that have been applied for in the same technology class and in the same year. Specifically, we count a patent as a radical patent if it falls into the $1 \%$ most cited patents; count a patent as an important patent if it falls into the $2 \%-10 \%$ most cited patents; count a patent as an incremental patent if it receives at least one citation but does not fall in the top 10\%; and count a patent as a failed patent if it receives zero citation. Then, we use the number of radical, important, incremental, and failed patents to measure the radical (Radical), important 
TABLE 4: Focused strategic corporate social responsibility and corporate innovation.

\begin{tabular}{|c|c|c|}
\hline \multirow[t]{2}{*}{ Variables } & $\operatorname{Ln}($ Patent +1$)$ & $\operatorname{Ln}($ Citation +1$)$ \\
\hline & (1) & (2) \\
\hline \multirow[t]{2}{*}{ FSCSR } & $0.462 * * *$ & $0.468 * * *$ \\
\hline & (6.29) & $(5.42)$ \\
\hline \multirow[t]{2}{*}{ RD/Sales } & $0.532 * * *$ & $0.560 * * *$ \\
\hline & (8.69) & (7.79) \\
\hline \multirow[t]{2}{*}{ Ln(Sales) } & $0.581 * * *$ & $0.617 * * *$ \\
\hline & $(18.40)$ & (17.49) \\
\hline \multirow[t]{2}{*}{ LEV } & $-0.764 * * *$ & $-0.907 * * *$ \\
\hline & $(-5.16)$ & $(-5.35)$ \\
\hline \multirow[t]{2}{*}{ ROA } & -0.289 & -0.434 \\
\hline & $(-1.08)$ & $(-1.37)$ \\
\hline \multirow[t]{2}{*}{ Cash/Assets } & $0.863 * * *$ & $0.897 * * *$ \\
\hline & $(3.90)$ & $(3.46)$ \\
\hline \multirow[t]{2}{*}{ SalesGrowth } & $0.169 * * *$ & $0.221 * * *$ \\
\hline & $(2.83)$ & $(2.97)$ \\
\hline \multirow[t]{2}{*}{$\mathrm{M} / \mathrm{B}$} & $0.024 * * *$ & $0.030 * * *$ \\
\hline & $(4.83)$ & $(5.04)$ \\
\hline \multirow[t]{2}{*}{ CapEx/Assets } & -0.861 & -0.379 \\
\hline & $(-1.29)$ & $(-0.49)$ \\
\hline \multirow[t]{2}{*}{ Ln(PPE/EMP) } & $0.196 * * *$ & $0.208 * * *$ \\
\hline & $(4.85)$ & $(4.60)$ \\
\hline \multirow[t]{2}{*}{ Ln(Sales/EMP) } & 0.013 & 0.023 \\
\hline & $(0.22)$ & $(0.36)$ \\
\hline \multirow[t]{2}{*}{ Constant } & $-4.041 * * *$ & $-4.205 * * *$ \\
\hline & $(-8.31)$ & $(-7.63)$ \\
\hline Industry FE & Yes & Yes \\
\hline Year FE & Yes & Yes \\
\hline$N$ & 8264 & 8264 \\
\hline Adjusted $R^{2}$ & 0.563 & 0.519 \\
\hline
\end{tabular}

FSCSR, focused strategic corporate social responsibility; RD, research and developmen expenditures; Ln, natural logarithm; LEV, capital structure; ROA, operating profitability; M/B, market-to-book ratio; CapEx, capital expenditures; PPE, net property, plant, and equipment, EMP, employees; $\mathrm{FE}$, fixed effects.

***,**, and *, denote significance at the $1 \%, 5 \%$, and $10 \%$ levels, respectively.

(Important), incremental (Incremental), and failed (Failed) innovative outputs for each company per year, respectively. The estimated coefficients in Panel A of Table 5 in all the regressions are positive and significant, indicating that SCSR not only has a positive effect on low-quality innovation but also on high-quality innovation, including radical patents. In the current economic reality, companies are facing unprecedented fierce competition, and radical innovation has become a key source of competitive advantage. We have verified that SCSR is a driving factor for radical innovation, which has certain practical value.

\section{Strategic corporate social responsibility and tolerance for failure}

In the hypothesis development, we argue that SCSR may affect innovation by improving firms' tolerance for failure. Higher uncertainty (Bloom, 2014), such as operating loss, may impair firms' ability to undertake risky investments in innovation. As a result, firms may delay or cut $R \& D$ investment to ensure survival. If SCSR helps gain trust from stakeholders, then we also expect to find that firms with SCSR are less likely to reduce R\&D investment when suffering uncertainty.

Specifically, we use RD/Sales to measure R\&D expenditure and use $\Delta R D /$ Sales to measure the change rate in $R \& D$ expenditure. The results are shown in Panel B of Table 5. In Column (1), the SCSR coefficient is positive, thus supporting the argument that firms with SCSR invest more in innovation. The SCSR coefficient is insignificant but positive in Column (3), and the coefficient is significantly positive in Column (2), suggesting that although firms with SCSR do not have a greater positive change in investment when suffering uncertainty, they still have higher R\&D investment. In sum, these results indicate that SCSR can increase failure tolerance, although the increase is limited.

\section{Strategic corporate social responsibility and short-term performance pressure}

Given that managers are the principal corporate decision makers, mitigating their short-term performance pressure matters to innovation. Generally, SCSR is an investment. If it provides quick and certain returns, then the performance pressure and short-sighted behaviour of managers will be reduced. To understand the extent to which SCSR might affect performance, we implement tests using cash holding (Cash/Assets) and sales growth (SalesGrowth) as dependent variables. Column (1) of Panel C of Table 5 shows a positive relationship between SCSR and cash holding. In Column (2), the coefficient is insignificant but positive. To further understand how SCSR affects sales growth, we use the change in sales growth ( $\Delta$ SalesGrowth) as dependent variable. Column (3) shows that firms with SCSR have more sales and a positive change in sales growth, suggesting that such firms face less performance pressure and less short-termism of the management, which our conjecture.

\section{Consistent engagement of strategic corporate social responsibility}

Consistent engagement of SCSR refers to participating in SCSR activities regularly and continuously (Tang, Hull, \& Rothenberg, 2012; Vermeulen \& Barkema, 2002). A consistent engagement helps stakeholders easily understand corporate strategy and build confidence. It helps employees increase their commitment to the company. To examine whether consistent engagement of SCSR has a greater effect on innovation, we construct Cons_SCSR as a measure of consistency.Cons_SCSR is equal to 1 if firms have participated in SCSR for two consecutive years, and 0 otherwise. To be robust, we also replace two consecutive years with 3 years to construct Cons_SCSR. Panel D of Table 5 presents the results. Evidence suggests that consistent engagement matters to innovation.

\section{Economic value of strategic corporate social responsibility} Strategic corporate social responsibility and patent value: Our results show that SCSR is positively related to corporate innovation, including important and radical innovation. However, our analyses have not shed light on the effect that SCSR has on actual commercial value. Following Stoffman et al. (2019), we measure patent value using the market reaction to patent announcements. We then use the perpetual inventory method to accumulate the estimated patent value for each firm in each year and 
TABLE 5A: Further analyses.

\begin{tabular}{|c|c|c|c|c|}
\hline \multirow[t]{2}{*}{ Variable } & Ln(Failed + 1) & Ln(Incremental + 1) & $\operatorname{Ln}(\operatorname{Important}+1)$ & Ln(Radical + 1) \\
\hline & (1) & (2) & (3) & (4) \\
\hline \multicolumn{5}{|c|}{ Panel A: SCSR and different categories of innovation } \\
\hline \multirow[t]{2}{*}{ SCSR } & $0.152^{* * *}$ & $0.138^{* * *}$ & $0.081 * * *$ & $0.025^{* * *}$ \\
\hline & (5.95) & (4.29) & (4.18) & (3.14) \\
\hline$N$ & 18845 & 18845 & 18845 & 18845 \\
\hline Adjusted $R^{2}$ & 0.416 & 0.464 & 0.344 & 0.189 \\
\hline
\end{tabular}

TABLE 5B: Further analyses.

\begin{tabular}{|c|c|c|c|}
\hline \multirow[t]{3}{*}{ Variable } & RD/Sales & RD/Sales & $\Delta$ RD/Sales \\
\hline & (1) & $\triangle \mathrm{ROA}<0$ & $\triangle \mathrm{ROA}<0$ \\
\hline & & (2) & (3) \\
\hline \multicolumn{4}{|c|}{ Panel B: SCSR and tolerance for failure } \\
\hline \multirow[t]{2}{*}{ SCSR } & $0.058^{* * *}$ & $0.065^{* * *}$ & 0.040 \\
\hline & $(4.21)$ & $(3.23)$ & $(0.66)$ \\
\hline \multirow[t]{2}{*}{ Ln(Sales) } & $-0.054 * * *$ & $-0.046 * * *$ & $-0.039 *$ \\
\hline & $(-8.04)$ & $(-5.26)$ & $(-1.83)$ \\
\hline$N$ & 15549 & 6165 & 4053 \\
\hline Adjusted $R^{2}$ & 0.432 & 0.473 & 0.046 \\
\hline
\end{tabular}

TABLE 5C: Further analyses.

\begin{tabular}{|c|c|c|c|}
\hline \multirow[t]{2}{*}{ Variable } & Cash/Assets & Salesgrowth & $\Delta$ Salesgrowth \\
\hline & (1) & (2) & (3) \\
\hline \multicolumn{4}{|c|}{ Panel C: SCSR and short-term performance pressure } \\
\hline \multirow[t]{2}{*}{ SCSR } & $0.006 * *$ & 0.002 & $0.015^{* * *}$ \\
\hline & $(2.06)$ & $(0.50)$ & $(3.22)$ \\
\hline$N$ & 15549 & 15549 & 15549 \\
\hline Adjusted $R^{2}$ & 0.316 & 0.171 & 0.127 \\
\hline
\end{tabular}

TABLE 5D: Further analyses.

\begin{tabular}{|c|c|c|c|c|c|c|}
\hline \multirow[t]{2}{*}{ Variable } & $\begin{array}{l}\text { Ln } \\
\text { (Patent } \\
+1)\end{array}$ & $\begin{array}{l}\operatorname{Ln} \\
\text { (Citation } \\
+1)\end{array}$ & $\begin{array}{l}\operatorname{Ln} \\
\text { (Failed } \\
+1)\end{array}$ & $\begin{array}{l}\text { Ln } \\
\text { (Incremental } \\
+1)\end{array}$ & $\begin{array}{c}\text { Ln } \\
\text { (Important } \\
+1)\end{array}$ & $\begin{array}{l}\operatorname{Ln} \\
\text { (Radical } \\
+1)\end{array}$ \\
\hline & (1) & (2) & (3) & (4) & (5) & (6) \\
\hline \multicolumn{7}{|c|}{ Panel D: Consistent engagement of SCSR } \\
\hline \multicolumn{7}{|c|}{ Consistency for 2 years in SCSR engagement } \\
\hline Cons_SCSR & $\begin{array}{c}0.229 * * * \\
(5.40)\end{array}$ & $\begin{array}{c}0.241^{* * *} \\
(5.07)\end{array}$ & $\begin{array}{c}0.193 * * * \\
(5.97)\end{array}$ & $\begin{array}{c}0.195 * * * \\
(4.99)\end{array}$ & $\begin{array}{c}0.109 * * * \\
(4.54)\end{array}$ & $\begin{array}{c}0.036^{* * *} \\
(3.53)\end{array}$ \\
\hline$N$ & 18845 & 18845 & 18845 & 18845 & 18845 & 18845 \\
\hline Adjusted $R^{2}$ & 0.476 & 0.433 & 0.417 & 0.465 & 0.345 & 0.190 \\
\hline \multicolumn{7}{|c|}{ Consistency for 3 years in SCSR engagement } \\
\hline Cons_SCSR & $\begin{array}{c}0.289 * * * \\
(5.54)\end{array}$ & $\begin{array}{c}0.290 * * * \\
(4.95)\end{array}$ & $\begin{array}{c}0.248 * * * \\
(5.96)\end{array}$ & $\begin{array}{c}0.252 * * * \\
(5.24)\end{array}$ & $\begin{array}{c}0.139 * * * \\
(4.60)\end{array}$ & $\begin{array}{c}0.043^{* * *} \\
(3.30)\end{array}$ \\
\hline$N$ & 18845 & 18845 & 18845 & 18845 & 18845 & 18845 \\
\hline Adjusted $R^{2}$ & 0.477 & 0.434 & 0.419 & 0.466 & 0.345 & 0.190 \\
\hline
\end{tabular}

TABLE 5E: Further analyses.

\begin{tabular}{ll}
\hline & Patent_value \\
\hline Panel E: SCSR and patent value & \\
SCSR & $0.307^{* * *}$ \\
& $(5.21)$ \\
$N$ & 7686 \\
Adjusted $R^{2}$ & 0.646 \\
\hline
\end{tabular}

calculate the natural logarithm of that value plus one. Panel E of Table 5 shows a strong positive association between SCSR and patent value (Patent_value). Thus, the result reveals that companies with SCSR will generate higher economic value. Therefore, SCSR engagement is beneficial to shareholders.
TABLE 5F: Further analyses.

\begin{tabular}{|c|c|c|c|}
\hline \multirow[t]{3}{*}{ Variable } & \multicolumn{3}{|c|}{ ROA } \\
\hline & Full sample & Strategic_CSR & Responsive_CSR \\
\hline & (1) & (2) & (3) \\
\hline \multicolumn{4}{|c|}{ Panel F: SCSR and effects of failed patents } \\
\hline \multirow[t]{2}{*}{$\operatorname{Ln}($ Failed +1$)$} & $-0.005^{* *}$ & -0.000 & $-0.009 * * *$ \\
\hline & $(-2.50)$ & $(-0.10)$ & $(-3.67)$ \\
\hline$N$ & 12967 & 5990 & 6977 \\
\hline Adjusted $R^{2}$ & 0.391 & 0.420 & 0.385 \\
\hline
\end{tabular}

Note: The control variables are included but not shown for saving space.

SCSR, strategic corporate social responsibility; RD, research and development expenditures; Ln, natural logarithm; ROA, operating profitability; CSR, corporate social responsibility; Cons_SCSR, consistent SCSR.

$* * *, * *$, and ${ }^{*}$ denote significance at the $1 \%, 5 \%$, and $10 \%$ levels, respectively.

Strategic corporate social responsibility and effects of failed patents: We find that relative to responsive CSR, SCSR has a significant and positive association with failed innovation. It will become an important concern if failed patents have a large negative influence on the development of the company. We now address this concern by examining the relationship between failed patents and corporate performance. The results are tabulated in Panel F of Table 5. Column (1) shows that the coefficient of $\operatorname{Ln}($ Failed +1$)$ of the full sample is significantly negative. Then, we divide the sample into two subsets, namely Strategic_CSR and Responsive_CSR. The results indicate that firms with SCSR are less likely to suffer loss than those with responsive CSR. The saying that failure is the mother of success is more applicable in firms with SCSR.

\section{Cross-sectional heterogeneity in results}

Effect of institutional ownership: Aghion et al. (2013) argue that institutional ownership is positively associated with innovation by protecting managers against reputational risk and reducing managers' career concern on risky projects. However, the short-termism of institutional investors may impede innovation. We classify firms with institutional ownership above (below) the industry median calculated based on the two-digit SIC code as having high (low) institutional ownership. Panel A of Table 6 shows that the $F$-values obtained from Chow tests are all significant. The results suggest that the positive relationship between SCSR and innovation is more pronounced in firms with lower institutional ownership.

Effect of firm size: Large firms are more likely to have explicit and implicit strengths that provide resources to promote the positive effect of SCSR on innovation. However, some specificities are associated with CSR activities in small businesses (Bocquet \& Mothe 2011). Innovation efficiency may be higher in small firms because of limited resources. Bocquet and Mothe (2011) use seven French cases and find that other than large companies, small companies can also spur radical innovation based on CSR involvement. To investigate the effect of firm size, we divide the sample into two subsets and classify firms with firm size above (below) the industry median calculated based on the two-digit SIC 
code as having large (small) firm size. Panel B of Table 6 shows that the positive relationship between SCSR and innovation is more pronounced in larger firms. However, in smaller firms, SCSR is more likely to drive important and radical innovation instead of failed and incremental innovation, thus indicating high innovation efficiency. The Chow tests suggest that the differences of SCSR coefficients between larger and smaller firms are significant, which confirms our findings.

Effect of product market competition: Recent theoretical and empirical models have found that innovation is affected by market competition. The Herfindahl index measures how competitive the industry is in which a firm operates (Aghion et al., 2005). It is measured based on total sales within the firm's two-digit SIC industry peers. Higher Herfindahl index indicates lower market competition. Panel C of Table 6 shows that the SCSR coefficients are more positive and significant when the product market competition is higher. Consistent with economic reality, the results verify that more competition yields more and higherquality innovation outputs.

\section{Conclusion}

Our study provides evidence in support of the effect of SCSR on corporate innovation and business success. Specifically, firms engaged in SCSR activities generate more and better innovation outputs, including radical and important patents. In comparison with diffused SCSR, FSCSR contributes more to innovation. From the perspective of possible mechanisms of action, higher tolerance for failure, lower short-term performance pressure and more consistent engagement of SCSR are critical. From the perspective of economic consequences, firms with SCSR actually have higher commercial value and are less likely to suffer loss from failed innovation. Finally, from the perspective of heterogeneity, the positive effect of SCSR on innovation is more pronounced when institutional ownership is lower, when firm size is larger, and when product market competition is more intense. Overall, our study offers novel evidence of the inspiring bright side of SCSR, that is, its boosting effect on more and higher-quality innovation outputs.

Corporate social responsibility is an important part of valuedriven management and when implemented effectively, it will be beneficial for all concerned and become a gateway for businesses to benefit the society and themselves. Strategic CSR is exactly a balance between traditional corporate profit maximisation and social wellbeing. Our results have a certain verification effect on the role of SCSR. To establish a sustainable relationship with stakeholders and realise the long-term development of business and society, an option we offer in this study for firms, especially those who want to spur high-quality innovation outcomes, is to engage in SCSR in a planned manner based on their own resources and professional expertise.

\section{Limitations and further research}

Although we have made preliminary attempts to understand the effects of SCSR, the study may not well answer to the

TABLE 6: Cross-sectional heterogeneity.

\begin{tabular}{|c|c|c|c|c|c|c|c|c|c|c|c|c|}
\hline \multirow[t]{3}{*}{ Variable } & \multicolumn{2}{|c|}{ Ln(Patent + 1) } & \multicolumn{2}{|c|}{$\operatorname{Ln}($ Citation + 1) } & \multicolumn{2}{|c|}{ Ln(Failed + 1) } & \multicolumn{2}{|c|}{ Ln(Incremental + 1) } & \multicolumn{2}{|c|}{ Ln(Important + 1) } & \multicolumn{2}{|c|}{ Ln(Radical + 1) } \\
\hline & High & Low & High & Low & High & Low & High & Low & High & Low & High & Low \\
\hline & (1) & (2) & (3) & (4) & (5) & (6) & (7) & (8) & (9) & $(10)$ & (11) & (12) \\
\hline \multicolumn{13}{|c|}{ Panel A: Effect of institutional ownership } \\
\hline \multirow[t]{2}{*}{ SCSR } & $0.158 * * *$ & $0.197 * * *$ & $0.179 * * *$ & $0.212 * * *$ & $0.143 * * *$ & $0.177 * * *$ & $0.129 * * *$ & $0.169 * * *$ & $0.065^{* * *}$ & $0.119 * * *$ & $0.015^{* *}$ & $0.047 * * *$ \\
\hline & $(6.18)$ & $(7.04)$ & $(6.05)$ & $(6.57)$ & (7.43) & (8.39) & $(5.62)$ & (6.49) & $(4.78)$ & (7.18) & (2.54) & $(5.64)$ \\
\hline$N$ & 10044 & 8801 & 10044 & 8801 & 10044 & 8801 & 10044 & 8801 & 10044 & 8801 & 10044 & 8801 \\
\hline Adjusted $\mathrm{R}^{2}$ & 0.439 & 0.535 & 0.390 & 0.498 & 0.390 & 0.473 & 0.421 & 0.529 & 0.279 & 0.427 & 0.148 & 0.253 \\
\hline Chow test & \multicolumn{2}{|c|}{6.45} & \multicolumn{2}{|c|}{6.11} & \multicolumn{2}{|c|}{6.75} & \multicolumn{2}{|c|}{7.20} & \multicolumn{2}{|c|}{9.12} & \multicolumn{2}{|c|}{8.38} \\
\hline$p$ & \multicolumn{2}{|c|}{0.00} & \multicolumn{2}{|c|}{0.00} & \multicolumn{2}{|c|}{0.00} & \multicolumn{2}{|c|}{0.00} & \multicolumn{2}{|c|}{0.00} & \multicolumn{2}{|c|}{0.00} \\
\hline \multicolumn{13}{|c|}{ Panel B: Effect of firm size } \\
\hline \multirow[t]{2}{*}{ SCSR } & $0.482 * * *$ & 0.030 & $0.506 * * *$ & $0.065^{* * *}$ & $0.397 * * *$ & 0.021 & $0.432 * * *$ & 0.020 & $0.243 * * *$ & $0.031 *$ & $0.089 * * *$ & $0.012^{*}$ \\
\hline & $(14.73)$ & (1.50) & $(13.83)$ & $(2.58)$ & (7.87) & (1.13) & $(7.42)$ & $(0.71)$ & $(6.56)$ & (1.92) & (5.16) & (1.91) \\
\hline$N$ & 9410 & 9435 & 9410 & 9435 & 9410 & 9435 & 9410 & 9435 & 9410 & 9435 & 9410 & 9435 \\
\hline Adjusted $\mathrm{R}^{2}$ & 0.433 & 0.305 & 0.410 & 0.242 & 0.344 & 0.207 & 0.426 & 0.280 & 0.312 & 0.113 & 0.162 & 0.032 \\
\hline Chow test & \multicolumn{2}{|c|}{61.72} & \multicolumn{2}{|c|}{52.38} & \multicolumn{2}{|c|}{57.28} & \multicolumn{2}{|c|}{63.32} & \multicolumn{2}{|c|}{48.46} & \multicolumn{2}{|c|}{21.56} \\
\hline$p$ & \multicolumn{2}{|c|}{0.00} & \multicolumn{2}{|c|}{0.00} & & & & & & & & \\
\hline Panel C: Effec & of product & rket comp & tion & & & & & & & & & \\
\hline SCSR & $0.236 * * *$ & 0.036 & $0.244 * * *$ & $0.053^{* *}$ & $0.222 * * *$ & $0.034 * *$ & $0.194 * * *$ & 0.011 & $0.112 * * *$ & 0.003 & $0.028 * * *$ & 0.008 \\
\hline & (7.93) & (1.57) & (7.03) & $(2.02)$ & (9.77) & $(2.06)$ & (7.17) & $(0.51)$ & $(6.66)$ & $(0.23)$ & (3.36) & (1.37) \\
\hline$N$ & 9430 & 9415 & 9430 & 9415 & 9430 & 9415 & 9430 & 9415 & 9430 & 9415 & 9430 & 9415 \\
\hline Adjusted $\mathrm{R}^{2}$ & 0.464 & 0.417 & 0.419 & 0.390 & 0.442 & 0.351 & 0.473 & 0.403 & 0.389 & 0.293 & 0.208 & 0.195 \\
\hline Chow test & & & & & & & & & & & & \\
\hline$p$ & & & & & & & & & & & & \\
\hline
\end{tabular}

Source:

Note: The control variables are included but not shown for saving space.

SCSR, Strategic corporate social responsibility.

$* * *, * *$, and $*$ denote significance at the $1 \%, 5 \%$, and $10 \%$ levels, respectively. 
question of how to combine SCSR with firms' business strategies. Moreover, although in practice, many companies have begun to realise the advantages of SCSR, empirical research on SCSR in academia is still at an early stage. An objective and direct measurement of SCSR is lacking, including the degree of integration of CSR practices with firms' business strategies. More research is needed to understand the importance of SCSR. With the in-depth practical development and academic development, SCSR will receive more attention and recognition to help companies make better decisions that render them more productive.

\section{Acknowledgements Competing interests}

The authors have declared that no competing interest exists.

\section{Authors' contributions}

Y.Z.Z. was responsible for formal analysis, methodology, writing and revision. S.H.N. was responsible for formal analysis, data collection and correspondence. S.W.Z. revised and edited the manuscript.

\section{Funding information}

This research was supported by the National Social Science Foundation of China (18BGL062), the Research Foundation of Education Bureau of Liaoning Province, China (LJKR0429), the National Natural Science Foundation of China (72002025).

\section{Data availability}

Data sharing is not applicable to this article as no new data were created or analysed in this study.

\section{Disclaimer}

The views and opinions expressed in this article are those of the authors and do not necessarily reflect the official policy or position of any affiliated agency of the authors.

\section{References}

Abdullah, N.H., Shamsuddin, A., Wahab, E., \& Hamidet, N.A.A. (2014). The relationship between organizational culture and product innovativeness. Procedia-Social and Behavioral Sciences, 129(15), 140-147. https://doi. Procedia-Social and Behavioral
org/10.1016/j.sbspro.2014.03.659

Aghion, P., Bloom, N., Blundell, R., Griffith, R., \& Howitt, P. (2005). Competition and innovation: An inverted-U relationship. Quarterly Journal of Economics, 120(2), 701-728. https://doi.org/10.1093/qje/120.2.701

Aghion, P., Van Reenen, J., \& Zingales, L. (2013). Innovation and institutional ownership. American Economic Review, 103(1), 277-304. https://doi.org/10.1257/ aer.103.1.277

Ajzen, I. (1991). The theory of planned behavior. Organizational Behavior and Human Decision Processes, 50(2), 179-211. https://doi.org/10.1016/0749-5978(91)90020-T

Atanassov, J. (2012). Do hostile takeovers stifle innovation? Evidence from antitakeover legislation and corporate patenting. Journal of Finance, 68(3), 1097-1131. https:// doi.org/10.1111/jofi.12019

Azoulay, P., Graff Zivin, J., \& Manso, G. (2011). Incentives and creativity: Evidence from the academic life sciences. RAND Journal of Economics, 42(3), 527-554. https:// doi.org/10.1111/j.1756-2171.2011.00140.x

Bagnoli, M., \& Watts, S.G. (2003). Selling to socially responsible consumers: Competition and the private provision of public goods. Journal of Economics and Management Strategy, 12(3), 419-445. https://doi.org/10.1111/j.1430-9134.2003.00419.x
Balsmeier, B., Fleming, L., \& Manso, G. (2017). Independent boards and innovation. Journal of Financial Economics, 123(3), 536-557. https://doi.org/10.1016/j. jineco.2016.12.005

Baron, D.P. (2001). Private politics, corporate social responsibility, and integrated strategy. Journal of Economics and Management Strategy, 10(1), 7-45. https:// doi.org/10.1111/j.1430-9134.2001.00007.x

Baron, D. P. (2009). A positive theory of moral management, social pressure, and corporate social performance. Journal of Economics and Management Strategy, 18(1), 7-43. https://doi.org/10.1111/j.1530-9134.2009.00206.x

Belu, C., \& Manescu, C. (2013). Strategic corporate social responsibility and economic performance. Applied Economics, 45(19), 2751-2764. https://doi.org/10.1080/00 036846.2012.676734

Bénabou, R., \& Tirole, J. (2010). Individual and corporate social responsibility. Economica, 77, 1-19. https://doi.org/10.1111/j.1468-0335.2009.00843.x

Bloom, N. (2014). Fluctuations in uncertainty. Journal of Economic Perspectives, 28(2), 153-176. https://doi.org/10.1257/jep.28.2.153

Bocquet, R., \& Mothe, C. (2011). Exploring the relationship between CSR and innovation: A comparison between small and largesized French companies. Revue Sciences de Gestion, Institut de Socio-Economie des Entreprises et des
Organisations (ISEOR), 101-119. Retrieved from https://hal.archives-ouvertes.fr/ hal-00919326/document

Boesso, G., Favotto, F., \& Michelon, G. (2015). Stakeholder prioritization, strategic corporate social responsibility and company performance: Further evidence.
Corporate Social Responsibility and Environmental Management, 22(6), 424-440. Corporate Social Responsibility and
https://doi.org/10.1002/csr.1356

Carroll, A.B. (1991). The pyramid of corporate social responsibility: Toward the moral management of organizational stakeholders. Business Horizons, 34(4), 39-48. https://doi.org/10.1016/0007-6813(91)90005-G

Chang, C. (2011). The influence of corporate environmental ethics on competitive advantage: The mediation role of green innovation. Journal of Business Ethics, 104, 361-370. https://doi.org/10.1007/s10551-011-0914-x

Chang, X., Fu, K., Low, A., \& Zhang, W. (2015). Non-executive employee stock options and corporate innovation. Journal of Financial Economics, 115(1), 168-188. https://doi.org/10.1016/j.jfineco.2014.09.002

Chemmanur, T.J., \& Tian, X. (2018). Do antitakeover provisions spur corporate innovation? A regression discontinuity analysis. Journal of Financial and Quantitative Analysis, 53(3), 1163-1194. https://doi.org/10.1017/S0022109018000029

Chen, C., Chen, Y., Hsu, P., \& Podolski, E.J. (2016). Be nice to your innovators: Employee treatment and corporate innovation performance. Journal of Corporate Finance, 39, 78-98. https://doi.org/10.1016/j.jcorpfin.2016.06.001

Chen, T., Dong, H., \& Lin, C. (2020). Institutional shareholders and corporate social responsibility. Journal of Financial Economics, 135(2), 483-504. https://doi. org/10.1016/j.jfineco.2019.06.007

Chen, Y., Hung, M., \& Wang, Y. (2017). The effect of mandatory CSR disclosure on firm profitability and social externalities: Evidence from China. Journal of Accounting and Economics, 65(1), 169-190. https://doi.org/10.1016/j.jacceco.2017.11.009

Choi, J., \& Wang, H. (2009). Stakeholder relations and the persistence of corporate financial performance. Strategic Management Journal, 30(8), 895-907. https:// doi.org/10.1002/smj.759

Cochran, P.L. (2007). The evolution of corporate social responsibility. Business Horizons, 50(6), 449-454. https://doi.org/10.1016/j.bushor.2007.06.004

Dal Maso, L., Lobo, G.J., Mazzi, F. \& Paugam, L. (2020). Implications of the joint provision of CSR assurance and financial audit for auditors' assessment of going concern risk. Contemporary Accounting Research, 37(2), 1248-1289. https://doi. concern risk. Contemporary Accou
org/10.1111/1911-3846.12560

Deng, X., Kang, J., \& Low, B.S. (2013). Corporate social responsibility and stakeholder value maximization: Evidence from mergers. Journal of Financial Economics, 110(1), 87-109. https://doi.org/10.1016/j.jfineco.2013.04.014

Flammer, C., \& Luo, J. (2017). Corporate social responsibility as an employee governance tool: Evidence from a quasi-experiment. Strategic Management Journal, 38(2), 163-183. https://doi.org/10.1002/smj.2492

Flor, M.L., Cooper, S., \& Oltra, M.J. (2017). External knowledge search, absorptive capacity and radical innovation in high-technology firms. European Management Journal, 36(2), 183-194. https://doi.org/10.1016/j.emj.2017.08.003

Foreh, M.R., \& Grier, S.A. (2003). When is honesty the best policy? The effect of stated company intent on consumer skepticism. Journal of Consumer Psychology, 13(3) 349-356. https://doi.org/10.1207/S15327663JCP1303_15

Forés, B., \& Camisón, C. (2016). Does incremental and radical innovation performance depend on different types of knowledge accumulation capabilities and organizational size. Journal of Business Research, 69(2), 831-848. https://doi. org/10.1016/j.jbusres.2015.07.006

Gallego-Álvarez, I., Prado-Lorenzo, J.M., \& García-Sánchez, I.M. (2011). Corporate social responsibility and innovation: A resource-based theory. Management Decision, 49(10), 1709-1727. https://doi.org/10.1108/00251741111183843

Hall, B.H., Jaffe, A.B., \& Trajtenberg, M. (2001). The NBER patent citation data file: Lessons, insights and methodological tools. National Bureau of Economic Research. https://doi.org/10.3386/w8498

Hall, B.H., Jaffe, A.B., \& Trajtenberg, M. (2005). Market value and patent citations. The RAND Journal of Economics, 36(1), 16-38. Retrieved from https://www.jstor.org/ stable/1593752

Heinkel, R., Kraus, A., \& Zechner, J. (2001). The effect of green investment on corporate behavior. Journal of Financial and Quantitative Analysis, 36(4), 431-449. https:// doi.org/10.2307/2676219 
Hillman, A.J., \& Keim, G.D. (2001). Shareholder value, stakeholder management, and social issues: What's the bottom line? Strategic Management Journal, 22(2), 125-139. issues: What's the bottom line? Strategic Management Journal, 22(2), 125-139. https://doi.org/1
SMJ150\%3E3.0.CO;2-H

Holmström, B. (1989). Agency costs and innovation. Journal of Economic Behavior and Organization, 12(3), 305-327. https://doi.org/10.1016/0167-2681(89)90025-5

Hong, H.G., \& Kostovetsky, L. (2012). Red and blue investing: Values and finance. Journal of Financial Economics, 103(1), 1-19. https://doi.org/10.1016/j. jfineco.2011.01.006

Husted, B.W., \& Allen, D.B. (2007). Strategic corporate social responsibility and value creation amongst large firms: Lessons from the Spanish experience. Long Range Planning, 40(6), 594-610. https://doi.org/10.1016/j.Irp.2007.07.001

Husted, B.W., \& Allen, D.B. (2009). Strategic corporate social responsibility and value creation. Management International Review, 49, 781-799. https://doi. org/10.1007/s11575-009-0016-5

Isaksson, L.E., Kiessling, T., \& Harvey, M. (2014). Corporate social responsibility: Why bother? Organizational Dynamics, 43(1), 64-72. https://doi.org/10.1016/j. orgdyn.2013.10.008

Khan, M.N., Serafeim, G., \& Yoon, A. (2016). Corporate sustainability: First evidence on materiality. The Accounting Review, 91(6), 1697-1724. https://doi. org/10.2308/accr-51383

Kogan, L., Papanikolaou, D., Seru, A., \& Stoffman, N. (2017). Technological innovation, resource allocation, and growth. The Quarterly Journal of Economics, 132(2), 665-712. https://doi.org/10.1093/qje/qjw040

Krüger, P. (2015). Corporate goodness and shareholder wealth. Journal of Financial Economics, 115(2), 304-329. https://doi.org/10.1016/j.jfineco.2014.09.008

Lins, K.V., Servaes, H., \& Tamayo, A. (2016). Social capital, trust, and firm performance: The value of corporate social responsibility during the financial crisis. Journal of Finance, 72(4), 1785-1824. https://doi.org/10.1111/jofi.12505

Luo, X., \& Du, S. (2015). Exploring the relationship between corporate social responsibility and firm innovation. Marketing Letters, 26, 703-714. https://doi. org/10.1007/s11002-014-9302-5

Magill, M., Quinzii, M., \& Rochet, J. (2015). A theory of the stakeholder corporation. Econometrica, 83(5), 1685-1725. https://doi.org/10.3982/ECTA11455

Manso, G. (2011). Motivating innovation. Journal of Finance, 66(5), 1823-1860. https://doi.org/10.1111/j.1540-6261.2011.01688.x

Mao, C.X., \& Weathers, J. (2019). Employee treatment and firm innovation. Journal of Business Finance \& Accounting, 46(7-8), 977-1002. https://doi.org/10.1111/ jbfa.12393

Martinez-Conesa, I., Soto-Acosta, P., \& Palacios-Manzano, M. (2017). Corporate socia responsibility and its effect on innovation and firm performance: An empirica research in SMEs. Journal of Cleaner Production, 142(4), 2374-2383. https://doi. org/10.1016/j.jclepro.2016.11.038

Melo, T., \& Garrido-Morgado, A. (2012). Corporate reputation: A combination of social responsibility and industry. Corporate Social Responsibility and Environmental Management, 19(1), 11-31. https://doi.org/10.1002/csr.260

Mcwilliams, A., \& Siegel, D.S. (2011). Creating and capturing value: Strategic corporate social responsibility, resource-based theory, and sustainable competitive advantage. Journal of Management, 37(5), 1480-1495. https://doi. org/10.1177/0149206310385696

Mcwilliams, A., Siegel, D.S., \& Wright, P.M. (2006). Corporate social responsibility: Strategic implications. Journal of Management Studies, 43(1), 1-18. https://doi. org/10.1111/j.1467-6486.2006.00580.x

Michelon, G., Boesso, G., \& Kumar, K. (2013). Examining the link between strategic corporate social responsibility and company performance: An analysis of the best corporate social responsibility and company performance: An analysis of the best
corporate citizens. Corporate Social Responsibility and Environmental corporate citizens. Corporate Social Responsibility and
Management, 20(2), 81-94. https://doi.org/10.1002/csr.1278

Mishra, D.R. (2017). Post-innovation CSR performance and firm value. Journal of Business Ethics, 140, 285-306. https://doi.org/10.1007/s10551-015-2676-3

Mithani, M.A. (2017). Innovation and CSR-Do they go well together? Long Range Planning, 50(6), 699-711. https://doi.org/10.1016/j.Irp.2016.08.002
Moser, P. (2005). How do patent laws influence innovation? Evidence from nineteenthcentury world's fairs. American Economic Review, 95, 1214-1236. https://doi. century world's fairs. American E$/ 1257 / 0002828054825501$
org

Moshirian, F., Tian, X., Zhang, B., \& Zhang, W. (2020). Stock market liberalization and innovation. Journal of Financial Economics, 139(3), 985-1014. https://doi. org/10.1016/j.jfineco.2020.08.018

Planer-Friedrich, L., \& Sahm, M. (2020). Strategic corporate social responsibility, imperfect competition, and market concentration. Journal of Economics, 129, 79-101. https://doi.org/10.1007/s00712-019-00663-x

Porter, M.E., \& Kramer, M.R. (2006). Strategy and society: The link between competitive advantage and corporate social responsibility. Harvard Business Review, 84(12), 78-92.

Riedl, A., \& Smeets, P. (2017). Why do investors hold socially responsible mutual funds? Journal of Finance, 72(6), 2505-2549. https://doi.org/10.1111/jofi.12547

Servaes, H., \& Tamayo, A. (2013). The impact of corporate social responsibility on firm value: The role of customer awareness. Management science, 59, 1045-1061. https://doi.org/10.1287/mnsc.1120.1630

Stoffman, N., Woeppel, M., \& Yavuz, M.D. (2019). Small innovators: No risk, no return Kelley School of Business Research Paper. https://doi.org/10.2139/ssrn.3291471

Stuebs, M., \& Sun, L. (2010). Business reputation and labor efficiency, productivity, and cost. Journal of Business Ethics, 96, 265-283. https://doi.org/10.1007/ s10551-010-0464-7

Sunder, J., Sunder, S.V., \& Zhang, J. (2017). Pilot CEOs and corporate innovation Journal of Financial Economics, 123(1), 209-224. https://doi.org/10.1016/j. jfineco.2016.11.002

Sydow, J., Schreyögg, G., \& Koch, J. (2009). Organizational path dependence: Opening the black box. Academy of Management Review, 34(4), 689-709. https://doi org/10.5465/amr.34.4.zok689

Tang, Z., Hull, C.E., \& Rothenberg, S. (2012). How corporate social responsibility engagement strategy moderates the CSR-financial performance relationship. Journal of Management Studies, 49(7), 1274-1303. https://doi. org/10.1111/j.1467-6486.2012.01068.x

Tsai, K., \& Liao, Y. (2017). Sustainability strategy and eco-innovation: A moderation model. Business Strategy and the Environment, 26(4), 426-437. https://doi. org/10.1002/bse.1926

Tsai, W., \& Ghoshal, S. (1998). Social capital and value creation: The role of intrafirm networks. Academy of Management Journal, 41(4), 464-476. https://doi. networks. Academy
org/10.5465/257085

Turban, D.B., \& Cable, D.M. (2003). Firm reputation and applicant pool characteristics. Journal of Organizational Behavior, 24(6), 733-751. https://doi.org/10.1002/job.215

Vermeulen, F., \& Barkema, H.G. (2002). Pace, rhythm, and scope: Process dependence in building a profitable multinational corporation. Strategic Management Journal, 23(7), 637-653. https://doi.org/10.1002/smj.243

Vishwanathan, P., Van Oosterhout, H., Heugens, P.P., Duran, P., \& Van Essen, M. (2020). Strategic CSR: A concept building meta-analysis. Journal of Management Studies, 57(2), 314-350. https://doi.org/10.1111/joms.12514

Waldman, D.A., Siegel, D.S., \& Javidan, M. (2006). Components of CEO transformational leadership and corporate social responsibility. Journal of Management Studies, 43(8), 1703-1725. https://doi.org/10.1111/j.1467-6486.2006.00642.x

Willard, B. (2002). The sustainability advantage: Seven business case benefits of a triple bottom line. Gabriola: New Society Publishers.

Wu, W., Liu, Y., Chin, T., \& Zhu, W. (2018). Will green CSR enhance innovation? A perspective of public visibility and firm transparency. International Journal of Environmental Research and Public Health, 15(2), 268. https://doi.org/10.3390/ ijerph15020268

Zhang, Y., Wang, H., \& Zhou, X. (2020). Dare to be different? Conformity vs. differentiation in corporate social activities of Chinese firms and market responses. Academy of Management Journal, 63(3), 1-52. https://doi.org/10.5465/amj.2017.0412

Zhou, K.Z., \& Li, C.B. (2012). How knowledge affects radical innovation: Knowledge base, market knowledge acquisition, and internal knowledge sharing. Strategic Management Journal, 33(9), 1090-1102. https://doi.org/10.1002/smj.1959 